\section{As Ciências Sociais e a licenciatura: perspectivas em torno dos primeiros períodos do curso.}

Anderson Santos

É difícil descrever os motivos que levam alguém a escolher as Ciências Sociais como curso, talvez por ser pouco divulgado do que se trata, tanto no ensino médio público quanto no privado. Entendo que escolher ingressar no curso, ainda mais na qualificação de licenciatura, não é uma tarefa das mais fáceis, visto a grande demanda das disciplinas e dos objetivos teóricos educacionais da qual faz parte na grade curricular. Ainda assim ao entrar no curso, deparei-me com um novo mundo repleto de formas de se pesquisar, entender e analisar o mundo ao meu redor. Este novo mundo se abre mediante uma forma específica de refletir as questões da realidade social, qual seja: a problematização, ${ }^{2}$ como formulou Michel Foucault, numa forma de se olhar a realidade que nos rodeia

\footnotetext{
1 Graduando em Licenciatura em Ciências Sociais pela Universidade Federal da Paraíba (UFPB). Membro do grupo de Estudos e Pesquisas de Pensamento Social e Político-Ariadne (UFPB). E-mail: andersondsc97@gmail.com.

${ }^{2}$ VINCI, Christian Fernando Ribeiro Guimarães. A problematização e as pesquisas educacionais: sobre um gesto analítico foucaultiano. Filosofia e Educação, v. 7, n. 2, 2015, p. 195-219.
}

com um certo distanciamento. Um curso que não teme dizer seu nome, e, como se não bastasse, incorpora três grandes áreas consolidadas em seus campos e na lida com seus objetos, sendo elas: Antropologia, Ciência Política e Sociologia.

Mas por que não fazer apenas um destes cursos separadamente como há ofertando em algumas universidades? Embora esse debate seja muito comum na academia, entre discentes e docentes, fazer Ciências Sociais é algo único. Seja pelo leque intelectual que abre aos graduandos, ou pela vasta atuação destes profissionais nos campos e objetos examinados.

Mesmo sabendo que nenhum curso de graduação é fácil, as Ciências Sociais se distingue dos demais, seja pela minha vivência no curso, ou pelos relatos de amigos e conhecidos dos mais variados cursos que a universidade nos disponibiliza conhecer. $O$ curso abre uma gama de possibilidades de atuação que não necessariamente se qualifica à docência, mesmo sendo uma de suas principais áreas empregatícias para atuação dos recém-formados.

Logo nos primeiros períodos do curso passamos por desconstruções sociais que põe em xeque o que "achamos" conhecer como certo e errado, as costumeiras convicções do senso comum. Aspectos educacionais e de teóricos da educação são vistos com mais profundidade. Reflexões sobre questões sociais, raciais, políticos e de gênero também são característicos no processo de ensino-aprendizagem do curso, ao menos assim seja quando a intenção de um entendimento cada vez mais abrangente acerca da vida social. Talvez esses 
elementos sejam cada vez mais patentes derivando da própria realidade contemporânea das pessoas que ingressam no curso, visto o crescente aumento de negros e negras nos cursos universitários nos últimos anos ${ }^{3}$, e de pessoas que tiverem que optar por cursos noturnos para poder ter um curso superior e conseguir conciliar com a sua ocupação profissional. Nesses casos, a grande maioria ingressam nas licenciaturas.

Não se precisa ir muito longe para se ver que os cursos universitários no Brasil são divididos por raça, classe e gênero. Não é uma divisão formal em termos oficiais da legislação, mas implícita nas turmas e no modo como esses cursos são programados, sendo eles integrais, matutinos, vespertinos ou noturnos. E onde fica as Ciências Sociais nisso? As Ciências Sociais, nos ajudam a entender que por mais que a sociedade seja regida por um turbilhão de fatores sociais que modifica a sociedade constantemente, incluindo os nossos padrões de vida, ações, gestos, cultura e religião. Ela nos concede o arcabouço necessário para analisar estas mudanças e explicar os fenômenos sociais que elas engendram.

As Ciências Sociais têm não só o intuito de formar novos cientistas sociais, mas de lançar à luz de seu tempo, pessoas comprometidas com a investigação social da sua realidade. Seja elas examinando os fatores econômicos,

\footnotetext{
3 "Cotas foram revolução silenciosa, afirma especialista". Disponível em: <http://agenciabrasil.ebc.com.br/educacao/noticia/2018-05/cotas-foramrevolucao-silenciosa-no-brasil-afirma-especialista\#>.
}

políticos, culturais ou religiosos. A partir disso, poderemos de fato entender que a licenciatura em Ciências Sociais e a docência se faz presente, mesmo diante dos aspectos negativos que rodeiam a perspectiva da classe professoral no Brasil.

Por mais que ainda seja pouco visto o que é Ciências Sociais, enquanto disciplina, o curso anualmente tem uma entrada considerável de alunos, no caso da Universidade Federal da Paraíba (UFPB) de onde falo geográfica e socialmente. Posso dizer que em nenhum momento me arrependi de ter escolhido este curso, pelo contrário, se pudesse escolher de novo, Ciências Sociais seria minha única opção. Venho observando e acrescentando na minha bagagem teórica e social de como a Sociologia auxiliou a me compreender enquanto perspectiva social. Enquanto a Ciência Política me ajudou a entender minha condição de indivíduo como uma existência política e, por fim, como a Antropologia me ajudou a entender o meu lugar enquanto negro e estudante de um curso de humanas na sociedade brasileira.

FALA, GRADUAND@! é uma seção destinada aos alunos e alunas de graduação em Ciências Sociais e áreas afins. Tem por objetivo a valorização de experiências acadêmicas e pessoas no ambiente universitário. Com isso, a seção procura promover um espaço de troca e diálogo com a comunidade acadêmica fora dos padrões convencionais de produção cientifica. Assim, são bem-vindos os depoimentos ou relatos de experiências, produções artísticas, como desenhos, charges, quadrinhos e trabalhos fotográficos. Acreditamos que a pluralidade de ideias é umas das principais características da Revista, assim, surgiu a proposta doFala, Graduand@. 